\title{
Yield, Quality Parameters and Economics of rice as influenced by Phosphorus Management in Rice-Groundnut sequence
}

\author{
M. Venkata Lakshmi ${ }^{1 *}$, CH. Pulla Rao ${ }^{1}$, P. V. N. Prasad ${ }^{1}$, \\ P. Prasuna Rani $^{2}$ and Y. Ashoka rani ${ }^{3}$ \\ ${ }^{1}$ Department of Agronomy, Agricultural College Farm, Bapatla, India \\ ${ }^{2}$ Geospatial Technology Centre Guntur, India \\ ${ }^{3}$ Department of Crop physiology, Agricultural College, Bapatlaa, Acharya N G Ranga \\ Agricultural University, Lam, Guntur, India \\ *Corresponding author
}

\section{A B S T R A C T}

\section{Keywords \\ Yield, Economics, in-situ green manuring, Phosphorus management and Rice}

\section{Article Info}

Accepted:

10 July 2020

Available Online:

10 August 2020

\begin{abstract}
A field experiment was conducted during Kharif 2016-17 and 2017-18 respectively on sandy loam soils of Agricultural College Farm Bapatla to study the yield, economics and quality parameters as influenced by phosphorus management in rice-groundnut sequence.The experiment was laid out in split plot design in Kharif rice and the treatments were replicated thrice. The treatments consisted of four main plots sources of phosphorus S1 : Inorganic fertilizer phosphorus through SSP, S2 : Green manuring in-situ with dhaincha@25 kg seed ha-1, S3 : Biofertilizer (PSB)@750 ml ha-1, S4 : Green manuring in-situ with dhaincha @ $25 \mathrm{~kg}$ seed ha-1 + Biofertilizer (PSB) @ $750 \mathrm{ml}$ ha-1 and three subplots levels of phosphorus L1 : 50\% Recommended dose of P, L2 : $100 \%$ Recommended dose of P and L3 : 150\% Recommended dose of P. Results of the experiment showed that application of in-situ green manuring + PSB along with inorganic phosphorus through SSP showed superior performance in terms of yield, quality parameters and economics over alone application of inorganic fertilizer phosphorus through SSP. Among the levels of phosphorus $150 \%$ RDP showed higher yield, quality parameters and economics over $50 \%$ RDP and however it was on par with $100 \%$ RDP.
\end{abstract}

\section{Introduction}

Rice (Oryza sativa L.) is one of the most important cereal crop. In India, rice ranks first among all the crops occupying $43.95 \mathrm{~m}$ ha area and production of $106.54 \mathrm{mt}$ with an average productivity of $2424 \mathrm{~kg} / \mathrm{ha}$ (CMIE, 2017-18). Among the fertilizer elements, phosphorus is an essential nutrient and no plant can produce good yield if it suffers from $\mathrm{P}$ deficiency. It is involved in the supply and transfer of energy for all biochemical processes in plants and hence, it is called as the "energy currency of living cells". It stimulates early root growth and development, encourages more active tillering, drymatter accumulation and promotes early flowering, maturity and good 
grain development. Further, optimum response to added nitrogen could be obtained only when adequate amount of $\mathrm{P}$ is supplied. Therefore, $\mathrm{P}$ availability from soils to the plant is the key to sustain higher yields. Green manures represent a promising approach to maintain sustainable nutrient supply for crop growth. The $\mathrm{P}$ in green manure could potentially be delivered to the soil in a form which is readily available to plants and soil microorganisms. Plants utilize less amounts of phosphatic fertilizers that are applied and the remaining portion is rapidly converted in to insoluble complexes in the soil. Slow mobility of applied phosphorus and its marked fixation results in low crop recoveries in the order of 20-25\%. Phosphate solubilizing bacteria (PSB) solubilize insoluble phosphorus and increase its availability phosphorus in the soil and inturn the overall phosphate use efficiency. Integrated use of chemical fertilisers with green manure crop and bio-fertilizer is important for sustainable rice production.

The increased prices of fertilizers also intensified the problem by increasing cost of inputs. so, trail was conducted with different doses of phosphorus levels in combinaion with in-situ green manur ing and psb then reduce the higher use of chemical fertilizers . The present study was, therefore, designed to find out the response of rice to sources and levels of phosphorus with regard to yield, quality and economics of rice.

\section{Materials and Methods}

The experiment was conducted at the Agricultural College Farm, Bapatla. Initial soil sample analysis revealed that the experimental soil was sandy loam in texture, slightly alkaline in reaction $(\mathrm{pH} 7.6,7.8)$, low in organic carbon $(0.42,0.43 \%)$, low in available nitrogen $\left(226,230 \mathrm{~kg} \mathrm{ha}^{-1}\right)$, low in available phosphorus $\left(18,20 \mathrm{~kg} \mathrm{ha}^{-1}\right)$ and high in available potassium $\left(483,521 \mathrm{~kg} \mathrm{ha}^{-1}\right)$ during 2016-17 and 2017-18 respectively. The experiment was laid out in a split plot design in Kharif rice and the treatments were replicated thrice. The treatments consisted of four main plots sources of phosphorus $S_{1}$ : Inorganic fertilizer phosphorus through SSP, $\mathrm{S}_{2:}$ Green manuring in-situ with dhaincha @ $25 \mathrm{~kg}$ seed ha ${ }^{-1}, \mathrm{~S}_{3}$ : Biofertilizer (PSB) @ 750 $\mathrm{ml} \mathrm{ha}{ }^{-1}, \mathrm{~S}_{4}$ : Green manuring in-situ with dhaincha@25 kg seed ha ${ }^{-1}+$ Biofertilizer (PSB) @ $750 \mathrm{ml} \mathrm{ha}^{-1}$ and three subplots levels of phosphorus $\mathrm{L}_{1}$ : $50 \%$ Recommended dose of $\mathrm{P}, \mathrm{L}_{2}: 100 \%$ Recommended dose of $\mathrm{P}$ and $\mathrm{L}_{3}$ : $150 \%$ Recommended dose of P. A very popular variety, BPT 5204 (Samba Mahsuri) was used for the study. The experimental field was ploughed twice by a tractor drawn cultivator, followed by a rotovator to obtain required tilth. The levelled field was then divided into the required number of main plots as per the layout plans. Dhaincha seed was broadcasted in the main plots namely $S_{2}$ (Green manuring@ $25 \mathrm{~kg} \mathrm{ha}^{-1}$ ) and $\mathrm{S}_{4}$ (Green manuring in situ + biofertilizer (PSB) @ 750 $\mathrm{ml} \mathrm{ha}^{-1}$ ) in all the three replications as per the layout plans and the seeds were covered by dragging a spike toothed harrow. These main plots (Green manure plots) were divided into sub plots after incorporation of green manure by making strong bunds and irrigation was given for better decomposition before transplanting of rice crop during both the years of experimentation.

A common dose of nitrogen at $120 \mathrm{~kg} \mathrm{ha}^{-1}$ was applied in the form of urea in three splits, half at basal, one fourth at active tillering and remaining at panicle initiation stage. Phosphorus in the form of single super phosphate was applied basal as per the treatments. A common dose of $40 \mathrm{~kg} \mathrm{~K}_{2} \mathrm{O} \mathrm{ha}^{-1}$ was applied as basal just before transplanting through muriate of potash by taking the plot size into consideration. 


\section{Quality parameters}

\section{Protein Content}

Grain nitrogen content (\%) estimated by microkjeldhal method (Jackson, 1973) was multiplied by the factor 6.25 and expressed as protein content (\%) of the grain.

Protein content $(\%)=$ Total $\mathrm{N}$ content $(\%) \mathrm{x}$ 6.25

\section{Amylose Content}

Grain amylose content was estimated as per the procedure as described by Sadasivam and Manickam (1992) and expressed as percentage.

\section{Procedure}

Weigh $0.1 \mathrm{~g}$ of the rice powdered sample, and add $1 \mathrm{ml}$ of distilled ethanol. Then add $10 \mathrm{ml}$ of $1 \mathrm{~N} \mathrm{NaOH}$ and leave it overnight. Make up the volume to $100 \mathrm{ml}$. Take $2.5 \mathrm{ml}$ extract, add about $20 \mathrm{ml}$ distilled water and then three drops of phenolphthalein. Add $0.1 \mathrm{~N} \mathrm{HCl}$ drop by drop until the pink colour just disappears. Add $1 \mathrm{ml}$ of iodine reagent and make up the volume to $50 \mathrm{ml}$ and read the colour at $590 \mathrm{~nm}$. Take $0.2,0.4,0.6,0.8$ and 1 $\mathrm{ml}$ of the standard amylose solution and develop the colour as in the case of sample. Calculate the amount of amylose present in the sample using the standard graph. Dilute 1 $\mathrm{ml}$ of iodine reagent to $50 \mathrm{ml}$ with distilled water for a blank.

\section{Volume Expansion Ratio}

Volume expansion ratio was determined as suggested by Verghese (1950) and modified by Murthy (1965) by using the following formula
Increase in volume after cooking (X-50)

Volume Expansion $=$

Increase in volume before cooking (Y-15)

Five grams of rice sample was soaked in $15 \mathrm{ml}$ of water for 5 minutes in a $50 \mathrm{ml}$ graduated centrifuge tube. The volume of water was recorded after adding rice samples ( $\mathrm{Y}-15)$. Rice cooked for 20 minutes in water bath was dipped in $100 \mathrm{ml}$ measuring cylinder (X) containing $50 \mathrm{ml}$ water. The volume raised was recorded (X-50) and was computed by using the above formula.

The gross returns from each treatment were worked out with the prevailing market prices. The net returns from each treatment were arrived at by deducting the cost of cultivation with the existing prices of inputs and wages of labour. Returns per rupee investment for all the treatments was worked out on the basis of net returns in terms of rupees after deducting the cost of treatments from gross returns.

Gross returns $=$ Value of the product $($ Grain + Straw)

Net returns $=$ Gross returns - Total cost of cultivation

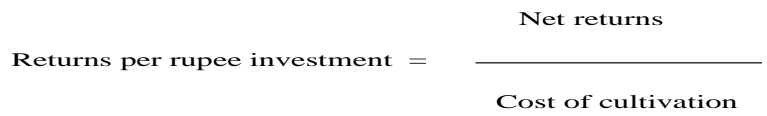

The gross returns from each treatment were worked out with the prevailing market prices. The net returns from each treatment were arrived at by deducting the cost of cultivation with the existing prices of inputs and wages of labour. Returns per rupee investment for all the treatments was worked out on the basis of net returns in terms of rupees after deducting the cost of treatments from gross returns. 
Gross returns $=$ Value of the product $($ Grain + Straw)

Net returns $=$ Gross returns - Total cost of cultivation

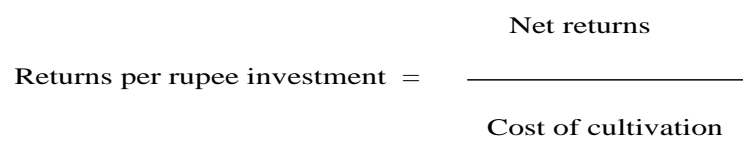

\section{Results and Discussion}

\section{Grain Yield $\left(\mathrm{kg} \mathrm{ha}^{-1}\right)$}

Grain yield was significantly influenced by sources and levels of phosphorus and their interaction too during both years of study and pooled data of study. The data pertaining to the grain yield of rice are presented in Table 1. The grain yield of various treatments was higher during the second year (2017-18) of study than that of the first year (2016-17). However the influence of different treatments was almost consistent in the both years of study and pooled data as well.

During both the years significantly higher yields were recorded with the treatment that received in combination with inorganic fertilizer through SSP and in-situ green manuring + biofertilizer (PSB) i.e. $5656 \mathrm{~kg}$ $\mathrm{ha}^{-1}, 5896 \mathrm{~kg} \mathrm{ha}^{-1}$ and $5776 \mathrm{~kg} \mathrm{ha}^{-1}$ during $1^{\mathrm{st}}$, $2^{\text {nd }}$ years and pooled data respectively, which was statistically on a par with in-situ green manuring treatment $(5520,5730$ and $5625 \mathrm{~kg}$ ha $^{-1}$ ) during $1^{\text {st }}$ and $2^{\text {nd }}$ years and pooled data respectively but proved significantly superior to alone inorganic fertilizer through SSP (4620, 4649, $4635 \mathrm{~kg} \mathrm{ha}^{-1}$ ) and biofertilizer (PSB) alone treatment (5179, 5329 and 5254 $\mathrm{kg} \mathrm{ha}^{-1}$ ) under test.

Total drymatter accumulation might have reflected on the economic yield in view of the fact that vegetative part of the plant serves as the source, where as the spikelets are serve as sink. Accumulation of drymatter during the vegetative growth stage and its distribution to yield attributes during reproductive stage through a process of translocation from source to sink and finally determines the economic yield of the crop.

Present study results showed that in-situ green manuring + biofertilizer (PSB) with inorganic fertilizer through SSP significantly influenced the grain yield of rice. Application of in-situ green manuring + biofertilizer (PSB) along with fertilizer was found to be superior in realizing maximum grain yield. It might be due to the fact that green manure biomass is a potential source of major nutrients for lowland rice and showed significant improvement in growth, yield, net returns, soil moisture retension, organic carbon and nutrient status of soil and reduction in bulk density of plough layer (Jyothi and Nallaiah (2015) and Siva Jyothi et al., 2013). The yield increase may be due to increase in growth attributes like drymatter production and yield attributes like panicle length, total number of grains, more number of filled grains per panicle. Similar findings were also reported by Arivukkarasu and Kathiresan (2007) and Deshpande and Devasenapathy (2010). Green manure + Biofertilizer (PSB) promotes improvement in leaf photosynthetic rate, biomass production and sink formation, which increased the grain yield of rice. Besides $\mathrm{P}$ solubilisation activity, PSB liberates growth harmone (IAA) that might have influenced on root growth and yield. The extensive root system might have increased nutrient uptake from the surroundings which boosted plant biomass and subsequently more grain yield of rice. These results were alike with the findings of Panhwar et al., (2010).

However, the lowest grain yield was recorded with inorganic fertilizer through SSP (4620 $\mathrm{kg} \mathrm{ha}^{-1}, 4649 \mathrm{~kg} \mathrm{ha}^{-1}$ and $4635 \mathrm{~kg} \mathrm{ha}^{-1}$ during $1^{\text {st }}, 2^{\text {nd }}$ year and pooled data of study). This might be due to phosphorus fixation in soil 
and lowest growth parameter like drymatter production and yield attributes like panicle length, total number of grains, more number of filled grains per panicle with SSP treatment.

Among the levels of phosphorus, $150 \%$ RDP recorded highest grain yield $(5425,5583$ and $5504 \mathrm{~kg} \mathrm{ha}^{-1}$ ) over $50 \%$ RDP (5024, 5164 and $5094 \mathrm{~kg} \mathrm{ha}^{-1}$ ) it was remained on a par with $100 \%$ RDP (5283, 5456 and $5369 \mathrm{~kg}$ ha $\left.{ }^{1}\right)$ during first, second and pooled data of study. This might be due to adequate supply of $\mathrm{P}$ in soil might have favoured efficient use of $\mathrm{P}$ in turn brought higher grain yield. These results are in close conformity with the findings obtained by Dutta and Gogoi (2009) and Ramesh Babu et al., (2013).

\section{Quality Parameters}

\section{Cooking quality parameters (Amylose and Volume expansion ratio)}

Data pertaining to cooking quality are presented in (Table 2 and Table 3 ) indicated that significant differences were observed in respect of amylose content and volume expansion ratio, among the various phosphorus sources and levels under study during both the years and pooled data of experimentation.

Significantly higher amylose content and volume expansion ratio were recorded with the treatment in-situ green manuring + biofertilizer (PSB) which was statistically on a par with in-situ green manuring. This might be due to higher total carbohydrates with the combination of in-situ green manuring + biofertilizer (PSB) of which may lead to higher alpha amylase activity. Starch is the major source of carbohydrate in rice which consists of amylase and amylopectin. Starch is biosynthesized from adenine disphosphate glucose of which $\mathrm{N}$ and $\mathrm{P}$ are constituents. Hence, amylose content increased due to application of nutrients was quite natural. Similar findings were reported by Dixit and Gupta (2000) and Vijayan and Krishnasamy (2014).

The significantly higher volume expansion ratio was noticed in in-situ green manuring + biofertilizer (PSB) which was on par with treatment in-situ green manuring. This may be due to application of organic manure gave a higher L/B ratio of rice after cooking than with inorganic fertilizer. Treatment with green manure + PSB has showed highest score by sensory evaluation in terms of overall acceptability with respect to colour, texture and taste of cooked rice. Similar findings were reported by Priyadarsini (2001) and Nguyen et al., (2002).

With regard to increasing levels of phosphorus increased amylose content and volume expansion ratio due to increased availability of nutrients. These findings are in close accordance with those of Yajie et al., (2012).

\section{Protein content}

A perusal of the data pertaining protein content (Table 4) showed significant differences due to various sources of phosphorus but not levels of phosphorus and their interaction during both the years and pooled data of study

During both the years and pooled data of study, it was observed that significantly higher protein content in grain was recorded with treatment that received in-situ green manuring + biofertilizer (PSB) $(8.4,8.6$ and $8.5 \%$ ), and was statistically remained on a par with in-situ green manuring (7.9, 8.1 and $8.0 \%$ ) but proved significantly superior to inorganic fertilizer through SSP alone (6.4, 6.5 and $6.4 \%$ ) and biofertilizer (PSB) alone treatments $(7.2,7.3$ and $7.2 \%)$. 
Table.1 Grain yield $\left(\mathrm{kg} \mathrm{ha}^{-1}\right)$ of Kharif rice as influenced by phosphorus management practices

\begin{tabular}{|c|c|c|c|}
\hline Treatments & 2016-17 & 2017-18 & Pooled data \\
\hline \multicolumn{4}{|l|}{ Source of phosphorus } \\
\hline$S_{1}$ - Inorganic phosphorus & 4620 & 4649 & 4635 \\
\hline$S_{2}$ - Green manuring & 5520 & 5730 & 5625 \\
\hline $\mathbf{S}_{3}$ - Soil application of PSB & 5179 & 5329 & 5254 \\
\hline $\mathrm{S}_{4}$ - Green manuring + PSB & 5656 & 5896 & 5776 \\
\hline S.Em \pm & 73.14 & 79.45 & 75.81 \\
\hline $\operatorname{CD}(p=0.05)$ & 253.1 & 274.9 & 262.3 \\
\hline CV $(\%)$ & 4.2 & 4.4 & 4.3 \\
\hline \multicolumn{4}{|l|}{ Levels of phosphorus } \\
\hline $\mathrm{L}_{1}-50 \%$ RDP & 5024 & 5164 & 5094 \\
\hline$L_{2}-100 \%$ RDP & 5283 & 5456 & 5369 \\
\hline $\mathrm{L}_{3}-150 \% \mathrm{RDP}$ & 5425 & 5583 & 5504 \\
\hline S.Em \pm & 55.92 & 70.28 & 57.21 \\
\hline CD $(p=0.05)$ & 167.7 & 210.7 & 171.5 \\
\hline $\mathrm{CV}(\%)$ & 3.7 & 4.5 & 3.7 \\
\hline Interaction & $\mathrm{s}$ & $\mathrm{S}$ & $\mathrm{S}$ \\
\hline
\end{tabular}

Table.2 Amylose content (\%) ratio of Kharif rice as influenced by phosphorus management practices

\begin{tabular}{|c|c|c|c|}
\hline Treatments & 2016-17 & 2017-18 & Pooled data \\
\hline \multicolumn{4}{|l|}{ Source of phosphorus } \\
\hline$S_{1}$ - Inorganic phosphorus & 19.4 & 20.1 & 20 \\
\hline$S_{2}$ - Green manuring & 22.9 & 25.0 & 24 \\
\hline$S_{3}$ - Soil application of PSB & 20.3 & 21.6 & 21 \\
\hline $\mathrm{S}_{4}$ - Green manuring + PSB & 23.9 & 26.0 & 25 \\
\hline S.Em \pm & 0.70 & 1.03 & 0.80 \\
\hline $\mathrm{CD}(\mathrm{p}=\mathbf{0 . 0 5})$ & 2.1 & 3.0 & 2.4 \\
\hline CV (\%) & 9.7 & 13.3 & 10.7 \\
\hline \multicolumn{4}{|l|}{ Levels of phosphorus } \\
\hline$L_{1}-50 \%$ RDP & 20.3 & 21.8 & 21 \\
\hline $\mathrm{L}_{2}-100 \% \mathrm{RDP}$ & 21.8 & 23.4 & 23 \\
\hline $\mathrm{L}_{3}-150 \% \mathrm{RDP}$ & 22.8 & 24.4 & 24 \\
\hline S.Em \pm & 0.55 & 0.52 & 0.53 \\
\hline $\mathrm{CD}(\mathbf{p}=\mathbf{0 . 0 5})$ & 1.6 & 1.5 & 1.5 \\
\hline CV $(\%)$ & 8.9 & 7.8 & 8.2 \\
\hline Interaction & NS & NS & NS \\
\hline
\end{tabular}


Table.3 Volume expansion ratio of Kharif rice as influenced by phosphorus management practices

\begin{tabular}{|c|c|c|c|}
\hline Treatments & 2016-17 & 2017-18 & Pooled data \\
\hline \multicolumn{4}{|l|}{ Source of phosphorus } \\
\hline$S_{1}$ - Inorganic phosphorus & 3.1 & 3.3 & 3.2 \\
\hline$S_{2^{-}}$Green manuring & 3.6 & 4.3 & 3.9 \\
\hline$S_{3}-$ Soil application of PSB & 3.2 & 3.6 & 3.4 \\
\hline$S_{4^{-}}$Green manuring + PSB & 4.1 & 4.9 & 4.5 \\
\hline S.Em \pm & 0.18 & 0.16 & 0.18 \\
\hline $\operatorname{CD}(p=0.05)$ & 0.5 & 0.4 & 0.5 \\
\hline $\mathrm{CV}(\%)$ & 15.0 & 12.2 & 14.0 \\
\hline \multicolumn{4}{|l|}{ Levels of phosphorus } \\
\hline $\mathrm{L}_{1}-50 \% \mathrm{RDP}$ & 3.0 & 3.5 & 3.3 \\
\hline$L_{2}-100 \%$ RDP & 3.4 & 34 & 3.7 \\
\hline $\mathrm{L}_{3}-150 \% \mathrm{RDP}$ & 4.1 & 4.6 & 4.3 \\
\hline S.Em \pm & 0.15 & 0.15 & 0.15 \\
\hline $\mathrm{CD}(\mathrm{p}=\mathbf{0 . 0 5})$ & 0.5 & 0.5 & 0.5 \\
\hline CV (\%) & 15.0 & 12.8 & 14.0 \\
\hline Interaction & NS & NS & NS \\
\hline
\end{tabular}

Table.4 Protein content (\%) of Kharif rice as influenced by phosphorus management practices

\begin{tabular}{|c|c|c|c|}
\hline Treatments & 2016-17 & 2017-18 & Pooled data \\
\hline \multicolumn{4}{|l|}{ Source of phosphorus } \\
\hline$S_{1}$ - Inorganic phosphorus & 6.4 & 6.5 & 6.4 \\
\hline $\mathrm{S}_{2}$ - Green manuring & 7.9 & 8.1 & 8.0 \\
\hline$S_{3}$ - Soil application of PSB & 7.2 & 7.3 & 7.2 \\
\hline $\mathrm{S}_{4}$ - Green manuring + PSB & 8.4 & 8.6 & 8.5 \\
\hline S.Em \pm & 0.16 & 0.16 & 0.16 \\
\hline $\mathrm{CD}(\mathrm{p}=\mathbf{0 . 0 5})$ & 0.5 & 0.5 & 0.5 \\
\hline CV (\%) & 6.3 & 6.1 & 6.2 \\
\hline \multicolumn{4}{|l|}{ Levels of phosphorus } \\
\hline $\mathrm{L}_{1}-50 \%$ RDP & 7.2 & 7.3 & 7.3 \\
\hline$L_{2}-100 \%$ RDP & 7.4 & 7.6 & 7.5 \\
\hline $\mathrm{L}_{3}-150 \% \mathrm{RDP}$ & 7.8 & 8.0 & 7.9 \\
\hline S.Em \pm & 0.25 & 0.25 & 0.25 \\
\hline $\mathrm{CD}(\mathrm{p}=\mathbf{0 . 0 5})$ & NS & NS & NS \\
\hline CV (\%) & 11.7 & 11.5 & 11.5 \\
\hline Interaction & NS & NS & NS \\
\hline
\end{tabular}


Table.5 Cost of cultivation (Rs.), Gross returns (Rs.), Net returns (Rs.) and Returns per rupee investment of Kharif rice as influenced by phosphorus management practices

\begin{tabular}{|c|c|c|c|c|c|c|c|c|c|c|c|c|}
\hline \multirow[t]{2}{*}{ Treatments } & \multicolumn{4}{|c|}{ 2016-17 } & \multicolumn{4}{|c|}{ 2017-18 } & \multicolumn{4}{|c|}{ Pooled data } \\
\hline & $\begin{array}{l}\text { Cost of } \\
\text { cultivation }\end{array}$ & $\begin{array}{l}\text { Gross } \\
\text { returns }\end{array}$ & $\begin{array}{l}\text { Net } \\
\text { returns }\end{array}$ & $\begin{array}{c}\text { Returns } \\
\text { per rupee } \\
\text { investment }\end{array}$ & $\begin{array}{l}\text { Cost of } \\
\text { cultivation }\end{array}$ & $\begin{array}{l}\text { Gross } \\
\text { returns }\end{array}$ & $\begin{array}{l}\text { Net } \\
\text { returns }\end{array}$ & $\begin{array}{c}\text { Returns } \\
\text { per rupee } \\
\text { investment }\end{array}$ & $\begin{array}{c}\text { Cost of } \\
\text { cultivation }\end{array}$ & $\begin{array}{l}\text { Gross } \\
\text { returns }\end{array}$ & $\begin{array}{l}\text { Net } \\
\text { returns }\end{array}$ & $\begin{array}{c}\text { Returns per } \\
\text { rupee } \\
\text { investment }\end{array}$ \\
\hline \multicolumn{13}{|l|}{ Source of phosphorus } \\
\hline$S_{1}$ - Inorganic phosphorus & 36750 & 73250 & 36500 & 0.99 & 35516 & 76000 & 40484 & 1.16 & 36133 & 74625 & 38492 & 1.08 \\
\hline$S_{2^{-}}$Green manuring & 40570 & 89984 & 49414 & 1.25 & 40349 & 93346 & 52997 & 1.34 & 40460 & 91665 & 51206 & 1.30 \\
\hline$S_{3}-$ Soil application of PSB & 39720 & 84373 & 44652 & 1.16 & 39472 & 86822 & 47350 & 1.23 & 39596 & 85598 & 46001 & 1.20 \\
\hline $\begin{array}{l}\text { S }_{4} \text { - Green manuring + } \\
\text { PSB }\end{array}$ & 40545 & 92060 & 51515 & 1.29 & 40328 & 95935 & 55607 & 1.40 & 40437 & 93998 & 53561 & 1.35 \\
\hline S.Em \pm & - & 1211.5 & 1212 & 0.03 & - & 1330.0 & 1330.0 & 0.03 & - & 1261.1 & 1261 & 0.03 \\
\hline $\mathrm{CD}(\mathbf{p}=\mathbf{0 . 0 5})$ & _- & 4192 & 4193 & 0.10 & _- & 4603 & 4603 & 0.12 & - & 4364 & 4364 & 0.11 \\
\hline CV (\%) & _- & 4.3 & 7.8 & 7.1 & _- & 4.5 & 8.1 & 7.8 & _- & 4.4 & 8 & 7.4 \\
\hline \multicolumn{13}{|l|}{ Levels of phosphorus } \\
\hline $\mathrm{L}_{1}-50 \%$ RDP & 38530 & 77350 & 38820 & 1.02 & 37950 & 77950 & 40000 & 1.05 & 38240 & 77650 & 39410 & 1.04 \\
\hline$L_{2}-100 \%$ RDP & 41080 & 87530 & 46450 & 1.13 & 41200 & 88840 & 47640 & 1.15 & 41140 & 88185 & 47045 & 1.14 \\
\hline $\mathrm{L}_{3}-150 \%$ RDP & 42550 & 89500 & 46950 & 1.10 & 43178 & 91150 & 47972 & 1.11 & 42864 & 90325 & 47461 & 1.11 \\
\hline S.Em \pm & _- & 879.0 & 879.1 & 0.02 & ----- & 1130.3 & 1130.3 & 0.03 & _- & 977.2 & 977.2 & 0.02 \\
\hline $\mathrm{CD}(\mathbf{p}=\mathbf{0 . 0 5})$ & _- & 2635 & 2636 & 0.06 & - & 3389 & 3389 & 0.09 & - & 2930 & 2930 & 0.07 \\
\hline CV $(\%)$ & - & 3.6 & 6.6 & 6.1 & - & 4.4 & 8.0 & 7.8 & - & 3.9 & 7.1 & 6.7 \\
\hline \multicolumn{13}{|l|}{ Interaction } \\
\hline S X L & - & NS & NS & NS & - & NS & NS & NS & - & NS & NS & NS \\
\hline L X S & - & NS & NS & NS & - & NS & NS & NS & - & NS & NS & NS \\
\hline
\end{tabular}


Among the levels of phosphorus, $150 \%$ RDP (7.8, 8.0 and $7.9 \%)$ recorded higher protein content followed by $100 \%$ RDP (7.4, 7.6 and $7.5 \%$ ) and $50 \% \operatorname{RDP}(7.2,7.3$ and $7.3 \%$ ) during both the years and pooled data of study. This might be due to accumulation of higher quantities of seed components like calcium carbonate and increased lipid metabolism which helps in increasing the protein content in seed which in turn increased nitrogen content in grain and also increased phosphorus levels with inoculation of PSB strains. Similar findings were also reported by Roy and Singh (2006) and Aslam et al., (2010).

\section{Economics}

The results of the trial showed that sources and levels of phosphorus but not their interaction had a significant influence on economics Kharif rice crop (Table 5 ). Gross returns, net returns and return per rupee invested were higher with in-situ green manuring + biofertilizer (PSB) which was closely followed by the treatment that received in-situ green manuring. This is due to lower cost of cultivation and higher grain and straw yields obtained with these treatments. Similar views were also expressed by Mondal et al., (2004).

The lower gross returns and net returns were obtained with inorganic fertilizer through SSP alone and biofertilizer (PSB) alone treatments. This is due to higher cost of cultivation and low grain and straw yield obtained with these treatments. These results are in conformity with the findings of Yogesh et al., (2013), Sharma et al., (2015) and Nanda et al., (2016).

\section{Gross Return (Rs.ha ${ }^{-1}$ )}

Gross returns from rice cultivation were influenced by sources and levels of phosphorus in both the years and pooled data of study (Table 5).

The highest gross return (Rs.92060and Rs. $95935 \mathrm{ha}^{-1}$ during 2016-17 and 2017-18, respectively) were realized with the combined application of in-situ green manuring + biofertilizer (PSB) which was superior over inorganic fertilizer through SSP and Biofertilizer (PSB) alone. The lowest gross return (Rs.73250 and Rs. $76000 \mathrm{ha}^{-1}$ during 2016-17 and 2017-18, respectively) were obtained with inorganic fertilizer through SSP. Among the levels of phosphorus $150 \%$ RDP recorded significantly higher gross return which was closely followed with 100 $\%$ RDP and was superior over $50 \%$ RDP.

Gross return from rice in response to sources and levels of phosphorus a distinctly descending order of in-situ green manuring + biofertilizer (PSB), in-situ green manuring, Biofertilizer (PSB), inorganic fertilizer through SSP during both the years of study. Similar findings were reported by Mehla and Panwar (2000).

\section{Net Return (Rs.ha $\left.{ }^{-1}\right)$}

Among the sources and levels of phosphorus to rice crop exhibited significant influence on net returns from rice crop during both the years of study (Table 5)

Net returns were the highest (Rs.51515 and Rs. $55607 \mathrm{ha}^{-1}$ during 2016-17 and 2017-18, respectively) with in-situ green manuring + biofertilizer (PSB), which was superior to inorganic fertilizer through SSP. The lowest net return (Rs.36500 and Rs.40484 ha ${ }^{-1}$ during 2016-17 and 2017-18, respectively) were recorded with the application of inorganic fertilizer through SSP. The trend of net returns was similar during both the years and pooled of investigation. Among the levels of phosphorus $150 \%$ RDP recorded 
significantly higher net return over $50 \%$ RDP which was closely followed with $100 \%$ RDP. Similar results were also reported by Kavitha and Subramanian (2007) and Moola Ram et al., (2011).

\section{Returns per rupee investment}

Returns per rupee investment was altered by sources and levels of phosphorus in both the years and pooled data of study (Table 5).

Combined use of green manure in-situ and PSB resulted in realizing the highest returns per rupee investment (1.29), which was superior to all other treatments. Supply of inorganic fertilizer through SSP was inferior to all other $\mathrm{P}$ sources, which resulted in the lowest BCR in both the years and pooled of study.

Among the sources of phosphorus, application of green manure in-situ + PSB attained significantly higher economic returns (Gross returns, Net returns and returns per rupee investment) during both the years owing to higher grain yield and in turn higher gross and net returns in this treatment. The beneficial effect of green manure and PSB in improving the net returns and returns per rupee investment was also reported by Prasad Rao and Bhupal Raj (2001) and Talathi et al., (2009).

Among the levels of phosphorus $150 \%$ RDP recorded significantly higher returns per rupee investment (1.10) over $50 \%$ RDP (1.02) which was closely followed with $100 \%$ RDP (1.13). Similar findings were also reported by Kumari et al., (2013) and Shahbaz et al., (2015).

\section{References}

Arivukkarasu and Kathiresan, R.M. 2007. Weed management in rice based cropping system. Proceedings of the $21^{\text {st }}$ asian Pacific weed science society conference. 24-27.

Aslam,M., Ahmad, HK., Himayatullah,AM., Ahmad, E., Sagoo, AG., Hussain, A and Manzoor, M. 2010. Nodulation, grain yield and grain protein contents as affected by rhizobium inoculation and fertilizer placement in chickpea cultivar. Journal of Agriculture. 26:467-474.

CMIE. 2016-17. Centre for Monitoring Indian Economy, http://commodities.cmie.com.

Deshpande, H. H and Devasenapathy, P. 2010. Effect of green manuring and organic manures on yield, quality and economics of rice (Oryza sativa L.) under low land condition. Karnataka Journal of Agriculture Science. 23(2): 235-238.

Dixit, K.G and Gupta, B.R. 2000. Effect of farm yard manure, chemical and biofertilizers on yield and quality of rice and soil properties. Journal of Indian Society of Soil Science. 48(4): 773-780.

Dutta, R and Gogoi, P.K. 2009. Direct and residual effect of phosphorus in winter rice (Oryza sativa)-groundnut (Arachis hypogaea L.) sequence. Research on Crops 10 (3): 484-488.

Jackson, M.L. 1973. Soil Chemical Analysis. Prentice Hall of India Private Limited, New Delhi. 41.

Jyothi, J.R. and Nallaiah, S.D. 2015. Influence of Integrated Nutrient Management Practices on Yield and Yield Attributes, and Economics of Transplanted Rice (Oryza Sativa L.) in South Zone of Tamil Nadu. International Journal for Innovative Research in Science \& Technology, 1(11): 462-466.

Kavitha, R and Subramanian, P. 2007. Effect of Municipal solid waste compost 
application on growth, plant nutrient uptake and yield of rice. Journal of Agronomy. 6 (4): 586-592.

Kumari, Niru, Pal, S.K and Sheela. 2013. Effect of organic nutrient management on productivity and economics of scented rice.Oryza.50 (3): 249-252.

Mehla, D.S and Panwar, D.V.S. 2000. Effect of organic and inorganic fertility levels on yield and yield components of scented rice. Indian Journal of Agricultural Sciences 7(3): $118-215$.

Mondal, S.S., Acharya, D., Ghosh, A and Thapa, U. 2004. Integrated management of organic and inorganic sources of nutrients to improve productivity and qualitative characters of rice and onion in rice-onion cropping sequence. Environment and Ecology 22(1): 125-128.

Moola Ram, M.R. Davari and Sharma, S.N. 2011. Effect of organic manures and biofertilizers on basmati rice (Oryza Sativa L.) under organic farming of rice-wheat cropping system. Inernational Journal of Agriculture and crop Sciences. 3(3):76-84.

Nanda, G., Sravan, U.S., Singh, A and Singh, S.P. 2016. Effect of NPK Levels and Bio-Organics on growth, yield and Economics of Basmati Rice (Oryza sativa L.) Cv HUBR 10-9. Environment \& Ecology 34(3): 1530-153

Nguyen,V.Q., Sharma, S.N and Gautam, R.C. 2002. Comparative study of organic and traditional farming for sustainable rice production. Omonrice, 10:74-78.

Panhwar, Q.A., Radziah, O., Rahman, Z., Sariah, M. and Razi, I.M. 2010. Role of phosphate solubilizing bacteria on rock phosphate solubility and growth of aerobic rice. Journal of Environmental Biology.32:607-612.

Prasad Rao and Bhupal Raj (2001). A text book on guidelines for soil based technologies to optimize land productivity in Andhrapradesh. Pp.56.

Priyadarsini, J. 2001. Yield and quality of rice as affected by varieties of nitrogen source. M.sc(Ag) Thesis submitted to Acharya NG Ranga Agricultural University, Hyderabad, India.

Ramesh Babu, P. V., Pulla Rao, Ch., Subbaiah, G., Veeraraghavaiah, R., Ashoka Rani, Y and Srininivas Rao, V. 2013. Effect of different levels of nitrogen and phosphorus on growth and yield of Kharif rice (Oryza sativa L.). The Andhra Agricultural Journal. 60 (3): 755-759.

Roy, D.K and Singh, B.P (2006). Effect of level and time of nitrogen application with and without vermicompost on yield, yield attributes and quality of malt barley (Hordeum vulgare). Indian Journal of Agronomy. 51: 40-42.

Sadasivam, S and Manickam, A. 1992. Biochemical methods for Agricultural Sciences. Wiley Eastern Limited. New Delhi. 10-11.

Shahbaz, M., Rasul, F., Saghir, A., Junaid, M.B., Mahaood, A and Ahmad.M. 2015. Bio-Economics and radiation use efficiency of basmati, hybrid and coarse grain (Oryza sativa). International Journal of Agricultural Science 89(4): 150-158.

Sharma, G. D., Thakur, R. K., Chouhan, N., Sharma, B. L and Tiwari, D. K. 2015. Effect of INM on yield, nutrient uptake, protein content \& economic performance of rice (Oryza sativa) and soil fertility in a vertisol. Green Farming 6(1): 50-54.

Siva Jyothi, V., Giridhara Krishna,T., Kavitha, P and Srinivasa Reddy. 2013. Influence of levels of phosphorus, FYM and Green manures on rice yield and economics in a phosphorus rich vertisol. The Andhra Agricultural Journal. 60 (4): 828-831.

Talathi, M.S., Pinjari, S.S., Ranshur, N.J., 
Bhondave, T.S and Suryawanshi, J.S. 2009. Prouctivity an economics of rice groundnut cropping system under integrated nutrient management. International Journal of Agricultural Sciences. 5(2): 472-476.

Verghese, E.J. 1950. Standard procedure for cooking rice for experimental purposes. Madras Agricultural Journal.36 (6): 217-221.

Vijayan, R and Krishnasamy, V. 2014. Impact of organic technics of seed crop management on seed yield and quality of Rice ADT 43. Academic journals, 9
(13): 611-618.

Yajie, Z., Jing-jing, H., Ya-chao, L., Yingying, C. and Jian-chang, Y. 2012. Effect of phosphorus on grain quality of upland and paddy rice under different cultivation. Rice Science, 19 (2): 135142.

Yogesh, TC., Viswanath, AP., Themmegowda, P.(2013). Yield and economics of aerobic paddy with application of zinc, iron and microbial inoculants. Journal of Environmental Science and Technology 2:100-104.

\section{How to cite this article:}

Venkata Lakshmi, M., CH. Pulla Rao, P. V. N. Prasad, P. Prasuna Rani and Ashoka rani, Y. 2020. Yield, Quality Parameters and Economics of rice as Influenced by Phosphorus Management in Rice-Groundnut sequence. Int.J.Curr.Microbiol.App.Sci. 9(08): 367-378. doi: https://doi.org/10.20546/ijcmas.2020.908.043 